DOI https://doi.org/10.18551/rjoas.2018-09.09

\title{
EFFECTS OF ORGANIZATIONAL COMMUNICATION AND WORKING GROUPS ON THE PERFORMANCE OF EMPLOYEES AT THE REGIONAL ENVIRONMENTAL AGENCY OF KUTAI KARTANEGARA REGENCY
}

\author{
Iskandar*, Turendy Deby, Sabran \\ Study Program of Management, Faculty of Economics and Business, \\ Kutai Kartanegara University, Indonesia \\ *E-mail: iskandar 76@rocketmail.com
}

\begin{abstract}
The purpose of this study was to determine and examine the effects of organizational communication and working groups on the performance of employees at the Regional Environmental Agency of Kutai Kartanegara Regency as well as to know the most dominant variable affecting the performance of employees at the Regional Environmental Agency of Kutai Kartanegara Regency. The analysis of data obtained by the researchers was done using multiple tools, multiple regression analysis, and SPSS rel12 application for Windows, resulting in the following regression equation: $Y=4.116+0,358 \times 1+0,338 \times 2$. Based on the equation, it was found that the variable of $X_{1}$ (organizational communication) amounted to $35.8 \%$, indicating that it has a significant influence on the performance of employees. Meanwhile, the variable of $X_{2}$ (working group) showed an effect of $33.8 \%$ on the employee performance, suggesting that organizational communication has the most dominant effect on the performance of employees. Thus, the second hypothesis was also accepted.
\end{abstract}

\section{KEY WORDS}

Organizational communication, working group, employee, performance.

Long-term human resource development is an increasingly important aspect of an organization. In general, the development of human resources is a goal of national development, which is the development of the nation. Meanwhile, specifically, the development of human resources is oriented to organizational environment. Human resources make other organizational resources able to run well. However, skilled, capable and ingenious human resources have not guaranteed the creation of good work performance. One of the benchmarks of the success of an organization in carrying out its development or operational activities is the work productivity level of employees in the organization. Organizations that can be said to be successful are those who have been able to achieve a maximal productivity with effective and efficient ways of work. In addition to skill and experience, organizational communication is also highly influential to employee work performance because bad communication process in working will negatively affect the results of work. Moreover, it is possible that the work results are not satisfying or not according to the desired expectation. Therefore, organizational communication in work can be said as one of the things that greatly support employee performance. Besides, working groups (dividing people into several teams) certainly have an effect on the performance of employees. Some people in a team/ group tend to give a less optimal performance, negatively affecting the completion of the assigned tasks.

Regional Environmental Agency is one of the Local Government institutions of Kutai Kartanegara Regency established based on the regional regulation of Kutai Kartanegara Regency Number 23 of 2008. Problems often occurring at the Regional Environmental Agency is miscommunications or misunderstandings, for example, the internal scope miscommunication between superiors and subordinates in carrying out their duties, causing many employees make mistakes while working or the work efficiency not comparable with the job. Meanwhile, in the division of working groups, there is often a gap between one to another in which the attention given by the superiors is uneven, making employees more strive in improving their work performances. The performance of employees should be built 
in a sustainable manner that is expected to increase the performance of both employees and the organization as a whole. Thus, performance-based management practices can involve target specification to be achieved and resource allocation, as well as measure and evaluate the performance. Target specification is a crucial element in formulating policies and programs in which both policies and programs are set to meet community needs. To realize the target needs resource allocation. Then, the performance is spelt out through performance indicators in the performance measurement design. According to Bawono (2009), performance will describe the level of achievement of the implementation of an activity, program, and policy in realizing the goals, targets, mission, and vision of a work unit within the government.

The purpose of this research was to determine and study the effects of organizational communication and working groups on the performance of employees at the Regional Environmental Agency of Kutai Kartanegara Regency, as well as to know the most dominant variable affecting the performance of the employees at the Regional Environmental Agency of Kutai Kartanegara Regency.

According to Emil Salin in his book entitled "The Aspect of Mental Attitude in Human Resource Management", performance is an individual work result on the given task that he carried out effectively and efficiently with his full responsibility (Emil Salim, 2000:73).

On the other side, Mangkunegara in his book entitled "Human Resource Management in Companies" stated that performance is the result of work in quality and quantity achieved by a public servant in carrying out his duties accordingly with the responsibilities given to him (Mangkunegara, 2001:67). Moreover, according to Hasibuan (2001:87), the meaning of work assessment is to assess the ratio between the real work result and the quality and quantity standards produced by every employee.

Based on some definition of performance expressed above, it can be concluded that performance is the result or the level of success someone achieves in his field of work according to certain criteria, which is evaluated by certain people, especially his superiors.

Wibowo (2008:76) defined that there are seven performance indicators, two of which have a very important role, namely goals and motives. Performance is determined by the purposes or goals to be achieved and to do so, motives are required. Without the driving factors or motives, performance will not run for reaching the goals. Thus, goals and motives are key indicators of performance. However, performance requires the support of facilities, competencies, opportunities, standards, and feedback.

The term of communication (in Indonesian komunikasi) derives from its Latin word which is similarly spelt "communication", and it is also sourced from the Latin word of "communis" which means "similar" (Effendi: 2007;9). However, the meaning of communication described above is basic, in the sense that communication at least must contain the similarity of meaning between the two parties involved. It is said to be minimal because communication activities are not only informative that make others understand and know, but also persuasive that make others willing to accept an understanding or belief, to perform an act or activity, and so on.

Another notion is that communication can be defined as a process of receiving information from the sender to the receiver by using various effective mediums so that the message can be clearly and easily understood by the receiver of the message (Banggun: 2008; 149).

Communication within an organization becomes important to create a common understanding or information conveyed to each other. According to Robbins (1996), communication is a transfer of meaning or understanding to others in the form of signs, symbols, or certain languages so that people who receive the information understand the purpose or meaning of the information conveyed.

An organization is a unity or association consisting of people or divisions in which there are cooperative activities based on the rules to achieve common goals (Pace and Faules, 2005). 
Several studies have revealed that communication shows a correlation with the overall together implementation of an organization. Furthermore, Pace and Faules (2005) stated that employees who have better information will be better employees as well.

Communication within an organization can occur in the form of written or spoken words, or symbols resulting in changes in the organization, either between managers and employees involved in giving information or exchanging information (Putu Sunarcaya, 2008).

According to Pace\& Faules (2005:150), based on its function, the flow of communication occurring within a formal organization consists of vertical flow (downward communication, upward communication), horizontal flow, and two-way communication:

- Downward Communication Flow;

- Upward Communication Flow;

- Horizontal Communication Flow;

- Two-way Communication.

For many employees, working is also a way to fill the need for social interaction (Robbins, 2006:182). It is, therefore, not surprising that having friendly and supportive coworkers will lead to increased job satisfaction. The behaviour of a boss is also a major determinant of satisfaction. It is no secret that most employees will feel a sense of satisfaction when their boss is friendly and understand themselves, praise their good performance, listen to their opinions and show a personal interest.

The definition of an organization working group is a group of people, consisting of two or more members with these following criteria (www.ellopedia.blogspot.com):

- Having the same goals;

- Having the same interests;

- Working together;

- Interconnected;

- Having a sense of belonging;

- Dependent on each other.

There are some reasons why people join in groups (www.ellopedia.blogspot.com):

- Security;

- Status;

- Self-esteem;

- Conjugation;

- Power;

- Good achievement.

Ranupandojo and Husnan (2006:195) stated that the desire to have a compact colleague is a reflection of social needs. An employee may feel objected to being promoted simply because he does not want to lose a compact co-worker. Furthermore, Nitisemito (2006:195) argued that the passion and excitement of work is essentially the manifestation of high work morale.

Shelley Mac Dermid, an assistant professor from Purdue University, in his research article entitled "Co-Workers closeness performance" of 1995 found a fact that work environments with a close interpersonal relationship can help the individuals overcome the problems existing in the workplace, which will also affect their performance at the workplace (findarticles.com).

From the empirical studies explained above, it was obtained an idea of the effects of organizational communications and working groups on employee performance. In detail, the idea is illustrated through this following framework:

After considering the description of the problems of this research, the researchers made provisional opinions or hypotheses as follows:

- Organizational Communication and Working Group have a significant effect on the performance of employees at the Regional Environmental Agency of Kutai Kartanegara Regency; 
- Organizational Communication is the most dominant factor that significantly influences the performance of employees at the Regional Environmental Agency of Kutai Kartanegara Regency.

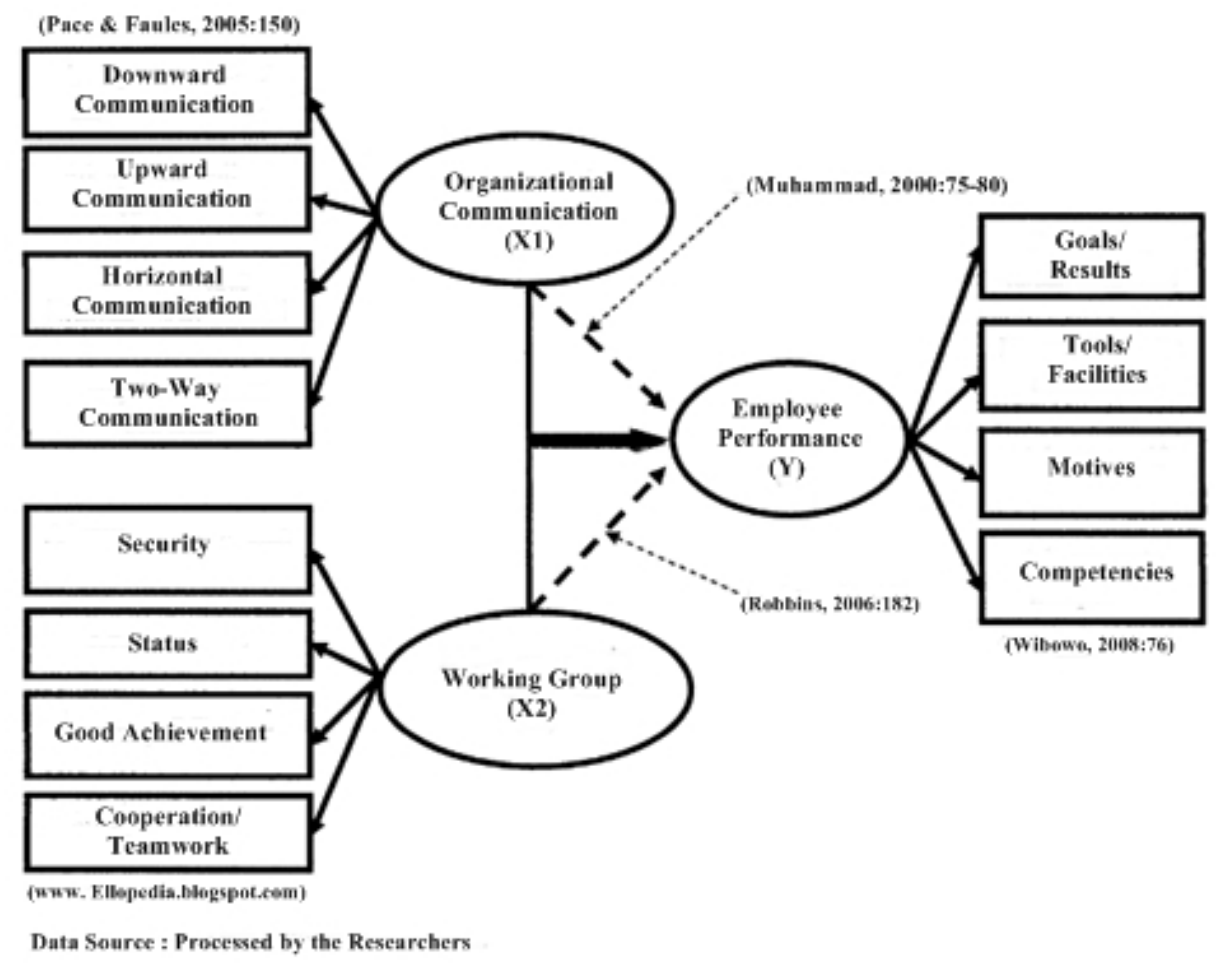

Figure 1 - Conceptual Framework

\section{METHODS OF RESEARCH}

In accordance with the title and discussion of this research, the object studied in this research was the Regional Environmental Agency of Kutai Kartanegara Regency which is precisely located in Akhmad Dahlan Street, Tenggarong District.

This research was conducted during March 2014. The population of this research was the civil servants (PNS) and freelance/ contracted employees working at the Regional Environmental Agency of Kutai Kartanegara Regency. The total population was 100 employees, consisting of 76 civil servants and 24 freelance/ contracted employees. Of the total population, the samples were taken according to Krejci table with $5 \%$ error level (Sugiyono, 2007,43) with a total sample number of 79 employees.

In analyzing the magnitude of the influence of Organizational Communication and Working Group on the Performance of Employees, it was used a tool of multiple linear regression analysis with this following equation model:

$$
\mathrm{Y}=\mathrm{a}+\mathrm{b}_{1} \mathrm{X}_{1}+\mathrm{b}_{2} \mathrm{X}_{2}+\hat{e} \text { (Sugiyono, 2007: 250) }
$$

Where: $Y=$ Performance; $X_{1}=$ Organizational Communication; $X_{2}=$ Working Group; $b_{1}, b_{2}=$ Partial Regression Coefficients; $a=$ Constant, i.e. the value of $Y$ that cannot be affected by variable $\mathrm{X}$; ê = Error or residual.

In analyzing, the researchers used the assistance of computer with SPSS (Statistical Product Service Solution) Version 17 program.

\section{RESULTS OF STUDY}

Based on the table above, the value of $R$ obtained was equal to 0.654 , meaning that there was a strong correlation of organizational communication variable and working group 
variable on the performance of employees at the Regional Environmental Agency of Kutai Kartanegara Regency because the number of 0.654 is above 0.5 and close to 1.0.

Meanwhile, the value of $R$ square $\left(R^{2}\right)$ is a value that shows the closeness of the correlation between independent and dependent variables. In this research, the value of $R$ square obtained was 0.428 deriving from 0.6542 . Because the value of $R$ square was greater than the value of adjusted $R$ square, the $R$ determination used was the value of $R$ square. That was, that the organizational communication and working group variables together or simultaneously influenced the employee performance variable at the Regional Environmental Agency of Kutai Kartanegara Regency as much as $42.8 \%$ and the rest $57.2 \%$ of the performance of employees $(100 \%-42.8 \%=57.2 \%)$ was influenced by other variables that were not examined or discussed in this study, such as motivation, incentive, and so forth. freedom):

The result of the F-test calculation was obtained by this following df (degrees of

$$
\begin{gathered}
\mathrm{df} 1=\mathrm{k}-\mathrm{I}=3-1=2 ; \text { and } \\
\mathrm{df} 2=\mathrm{n}-\mathrm{k}=79-3=76
\end{gathered}
$$

Therefore, the $F$ table obtained 3.12, meaning that the calculated $F\left(F_{\text {count }}\right)>$ tabulated $F\left(F_{\text {table }}\right)$ or $28.404>3.12$. From the calculated $F$ value of 28.404 , it was obtained the probability level of 0.000 . Since the probability level was much smaller if compared to 0.05 , the regression model could be used to predict the employee performance. Thus, the first hypothesis posed by the researchers in this research ("Organizational Communication and Working Group have a significant effect on the performance of employees at the Regional Environmental Agency of Kutai Kartanegara Regency") was accepted and proven to be valid.

Table 1 - F Test Results

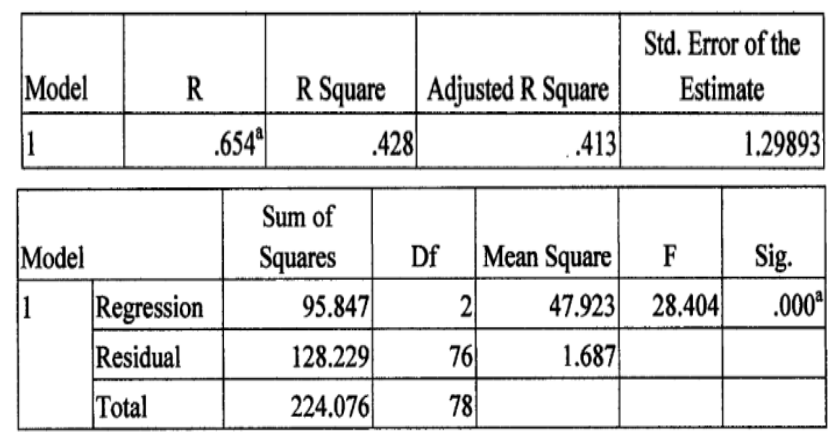

Data Source: SPSS Output, processed 2014. follows:

Based on the SPSS outputs, it can be seen that the $t$-value of each variable is as

Table 2 - t-Test Results

\begin{tabular}{|l|l|l|l|l|l|}
\hline No & Variable & $t$-Test & $t$-Table & Sig. & Conclusion \\
\hline 1 & Organizational Communication & 3.307 & 1.991 & 0.001 & Significant \\
\hline 2 & Working Group & 4.070 & 1.991 & 0.000 & Significant \\
\hline
\end{tabular}

Data Source: SPSS Output, processed 2014.

The $t$-table value of 1.991 was calculated using the formula of degrees of freedom (df) in which $n-2=79-2=77$, and the alpha $(a)=0.05$.

Based on the table above, it can be explained that:

The organizational communication variable $\left(X_{1}\right)$ obtained $t_{\text {count }}=3.307>t_{\text {table }}=1.991$ and Sig. or $(p)=0.001<0.05$, indicating that $\mathrm{H}_{0}$ was rejected and $\mathrm{H}_{\mathrm{a}}$ was accepted. In other words, the organizational communication variable was partially or severally able to show a 
significant effect on the performance of employees at the Regional Environment Agency of Kutai Kartanegara Regency.

In addition, the research results showed that the organizational communication variable positively affected the performance of employees at the Regional Environment Agency of Kutai Kartanegara Regency. These results prove that vertical communication (upward and downward communications), horizontal communication, and two-way communication within an organization can influence the performance of employees at the Regional Environment Agency of Kutai Kartanegara Regency.

The working group variable $\left(X_{2}\right)$ obtained $t_{\text {count }}=4.070>t_{\text {table }}=1.991$ and Sig. or $(p)=$ $0.000<0.05$, indicating that $\mathrm{H}_{0}$ was rejected and $\mathrm{H}_{\mathrm{a}}$ was accepted. In other words, the working group variable was partially or severally able to show a significant effect on the performance of employees at the Regional Environment Agency of Kutai Kartanegara Regency.

The research results suggested that the working group variable positively affected the performance of employees at the Regional Environment Agency of Kutai Kartanegara Regency. These results also prove that the security, status, good achievement and cooperation or teamwork can influence the performance of employees at the Regional Environment Agency of Kutai Kartanegara Regency.

Based on the calculation results explained above, it can be seen that the organizational communication variable $\left(\mathrm{X}_{1}\right)$ was the most dominant factor, which was partially able to show its influence significantly to the performance of employees. Meanwhile, the working group variable was the second most dominant factor in predicting or determining the performance of employees at the Regional Environment Agency of Kutai Kartanegara Regency. Thus, the second hypothesis proposed by the researchers in this research ("Organizational Communication is the most dominant factor that significantly influences the performance of employees at the Regional Environmental Agency of Kutai Kartanegara Regency") was accepted and proved to be valid.

\section{DISCUSSION OF RESULTS}

The regression equation is as follows:

$$
Y=4.116+0.358 X_{1}+0.338 X_{2}
$$

The constant value of 4.116 indicates that if there were no independent variables (Organizational Communication and Working Group), the employee performance value would be 4.116. Based on the equation, it can be interpreted that any changes in both $X_{1}$ and $\mathrm{X}_{2}$ would positively influence $\mathrm{Y}$ (employee performance). The constant value (a) resulted of 4.116 also states that if the organizational communication and working group variables were null, the performance of employees at the Regional Environmental Agency of Kutai Kartanegara Regency would be 4.116 or increase by $411.6 \%$.

The regression coefficient of the organizational communication obtained 0.358 . It means that if the organizational communication variable was increased by one unit, the performance of employees would improve by $35.8 \%$.

On another side, the regression coefficient of the working group obtained 0.338 . It indicates that if the working group variable was increased by one unit, the performance of employees would improve equal to $33.8 \%$.

\section{CONCLUSION}

Based on the results of the data analysis and discussion of this research, it can be drawn conclusions as follows:

- The organizational communication and working group variables are together able to show significant effects on the performance of employees. Therefore, the first hypothesis is accepted. 
- The organizational communication has the most dominant effect on the performance of employees. Thus, the second hypothesis is accepted.

\section{REFERENCES}

1. Ami, M. (2000). Komunikasi Organisasi. Jakarta: PT. Bumi Aksara.

2. Bangun. (2008). Intisari Manajemen. Bandung: PT Refika Aditama

3. Bawono, S. (2009). Kecerdasan Entrepreneur. Jakarta: PT Elex Media Komputindo

4. Effendi, O. C. (1992). Spektrum Komunikasi. Bandung: Mandar Maju.

5. Faules, P. (2005). Komunikasi Organisasi $\left(3^{\text {rd }}\right.$ Ed). Bandung: Penerbit Remaja Rosda Karya.

6. Hasibuan, M. S. P. (2001). Manajemen Sumber Daya Manusia (4 ${ }^{\text {th }}$ Ed). Jakarta: Bumi Aksara, Jakarta

7. Nitisemito, 2006, Manajemen Personalia $\left(2^{\text {nd }}\right.$ Ed). Surabaya: Ghalia Indonesia

8. Mangkunegara, A. P. (2004). Manajemen Sumber Daya Manusia Perusahaan. Bandung: PT. Remaja Rosda Karya.

9. Moekijat. (1999). Pengawasan yang Efektif. Bandung: CV. Mandar Maju.

10. Pace \& Faules. (2005). Komunikasi Organisasi, Strategi Meningkatkan Kinerja Perusahaan. Bandung: PT. Remaja Rosdakarya.

11. Ranupandojo., \& Husnan. (2002). Manajemen Personalia. Yogyakarta: BPFE UGM.

12. Robbins, S. P. (2006). Perilaku Organisasi $\left(10^{\text {th }}\right.$ Ed). Jakarta: PT Indeks Kelompok Gramedia.

13. Robbins, S. P. (1996). Perilaku Organisasi. Jakarta: Prenhallindo

14. Sugiyono. (2007). Metode Penelitian Pendidikan Pendekan Kuantitatif, Kualitatif, dan R\&D. Bandung: Alfabeta.

15. (2005). Metode Penelitian Kualitatif, Bandung: Alfabeta.

16. Wibowo. (2008). Manajemen Kinerja ( $2^{\text {nd }}$ Ed). Jakarta: PT. Raja Grafindo Persada.

17. Electronic Source: www.ellopedia.blogspot.com. 